\title{
Is there a relationship between financial development and economic growth in Latin American countries with higher per capita GDP?
}

\author{
Rodríguez-Nava, Abigail \\ - ReCeIVED: 24 JULY 2013 \\ - accepted: 20 january 2014
}

Venegas-Martínez, Francisco

\begin{abstract}
This paper aims to analyze the relationship between financial development and economic growth in Latin American countries with higher per capita GDP. To do this, a regression model for panel data is used. The results of several econometric tests show that models that best fit the data are those with fixed effects and instrumental variables; however, there is no clear evidence that financial development leads to economic growth, which may indicate that in order to explain this linkage it is essential to consider other variables such as macroeconomic stability and institutional strength.
\end{abstract}

\section{Keywords:}

Financial development, Economic growth, Latin American countries.

JEL classification:

F43, G15, G18.

Venegas-Martínez, F., Escuela Superior de Economía, Instituto Politécnico Nacional, Cerro del Vigía I5, Colonia Campestre Churubusco, Delegación Coyoacán, 04200, D.F. México. E-mail: fvenegas I I I @yahoo.com.mx 


\section{¿Existe una relación entre el desarrollo financiero y el crecimiento económico en los países latinoamericanos con mayor PIB per cápita?}

Venegas-Martínez, Francisco

Rodríguez-Nava, Abigail

\section{Resumen}

Esta investigación analiza la relación entre desarrollo financiero y el crecimiento económico en los países latinoamericanos con mayor PIB per cápita. Para ello, se utiliza un modelo de regresión de datos de panel. Los resultados de diversas pruebas econométricas muestran que los modelos que mejor ajustan los datos son los de efectos fijos con variables instrumentales; sin embargo, no existe clara evidencia de que el desarrollo financiero conduzca al crecimiento económico, lo cual puede indicar que para explicar dicha relación es importante considerar otros factores, tales como la estabilidad macroeconómica o la fortaleza de las instituciones.

\section{Palabras clave:}

Desarrollo financiero, crecimiento económico, Latinoamérica. 


\section{Introduction}

There has been an ongoing debate about the role of financial markets in economic stability and economic growth. In the on-going financial crisis and the still persistent effects of the prior global economic and financial crisis of 2007-2009, many criticisms have been leveled towards the expansion of financial markets. These criticisms are focused on the causes that led to, and expanded, the economic instability. In this regard, there are several causes related to the critical performance of the financial sector, some which are as follows: 1) the exacerbated issuance of securities ensuring higher short term returns; 2) the deliberated omission in monitoring the risk market associated with new synthetic instruments; 3 ) the limited regulation, supervision, and control of financial market and their volatility by the monetary authority; 4) the euphoria and confidence in the markets due to the perception of low risk; 5) the large number of loans approved without guarantees; 6) the asset securitization activities; 7) and, finally, the exacerbated indebtedness by all economic agents (households, firms, and governments). Given the negative impact of the above events and the significant detrimental impact on macroeconomic variables such as output, savings, investment, consumption, and employment, it seems to be that financial development is harmful; however, there are many studies that indicate the opposite, i.e., asserting that financial development is beneficial mainly to economic growth, but there is less clarity on additional factors that add to this result.

One major question that can be posed regarding the inequality that exists in developing countries with respect to the percentage of the population that use banking services (to manage accounts, receive wages and make payments) or other financial services (such as applying for loans) is whether this percentage has some effect on output growth. In some empirical studies, it has been found that countries with higher per capita income are strongly correlated with the use of banking services including access to funding sources for firms, which, in turn, has positive effects on the real sector. Some of these studies have examined this correlation by using measures of financial inclusion suggested by the theory as pointed out by DemirgucKunt and Klapper (2012). In this regard, there is a set of indicators of financial inclusion provided and computed by Findex, but the analysis is still limited, since data are available for only some periods of time. ${ }^{1}$ On the other hand, empirical literature has also shown that microfinance services have contributed to an improvement in the quality of life of the poor in various regions of the world, by providing access to finance for family projects that may have some (moderate) effect on the productive sector (Sengupta and Aubuchon, 2008).

\footnotetext{
'The Global Financial Inclusion (Global Findex) database is a project of the World Bank that attempts to measure how people in
} 148 countries, including the poor, women, and rural residents, save, borrow, make payments and manage risk. 
The banks are usually the financial intermediaries that provide services and technical assistance to individuals investing in capital markets. In this regard, the banks mobilize resources in capital markets, generate knowledge through technical assistance, and supply a range of complementary services for investment in the capital markets. The Latin American countries have formed a strong network of institutions in capital markets, where competition and complementation have led their dynamics. These countries have had great potential in comparison to other regions due to their strength in allocating resources among stakeholders and financial institutions, as well as innovating financial instruments.

The objective of this research is to analyze the relationship between financial development and economic growth in Latin American countries with higher per capita income (Argentina, Brazil, Chile, Colombia, Mexico, Uruguay and Venezuela) for the period 1990-2011. The results from regression models for panel data (pooled data, fixed effects, random effects and fixed effects with instrumental variables) have not shown a clear relationship between the two main variables, which may indicate that other associated variable could explain this linkage, for example, stability of macroeconomic variables or institutional strength of institutions.

The paper is organized as follows: section 2 presents some relevant economic literature about the relationship between financial development and economic growth, and identifies the key aspects in the issue of financial inclusion; section 3 briefly presents some indicators of financial development in Latin America; section 4 discusses the results of the proposed econometric model used to examine the relationship between financial development and growth; and, finally, section 5 provides the conclusions.

\section{Financial development and output growth}

One of the main assumptions of the behavior of the financial sector, mainly from orthodox financial economics, is the financial deepening of markets. This hypothesis establishes that there is a positive association between the degree of financial development in a region and its economic growth. There are, basically, three lines of research associated with this hypothesis: supply-leading, demand-following, and bidirectional causality.

The supply-leading approach asserts that the financial development of a region determines the magnitude of economic growth, and because financial intermediation is strengthened it follows that: 1) transaction costs are reduced, 2) supply of services is increased, 3) access to foreign capital is increased, 4) efficient use of resources is 
greater, and 4) both productive investment and commercial activity are stimulated. This approach considers the contributions from McKinnon (1973), Shaw (1973), Gupta (1984), Greenwod and Jovanovich (1990), King and Levine (1993), De Gregorio and Guidotti (1995), Levine et al. (2000), Nazmi (2005) and Acaravci et al. (2009). In particular, De Gregorio and Guidotti (1995) emphasize that the lower the financial regulation, the lower the positive impacts. They also show that if investment is considered as the main channel of transmission, then the efficient use of resources becomes more relevant than the amount of capital. Moreover, Levine et al (2000), from a study for 74 countries between 1960 and 1995, found a positive link between financial intermediary development and economic growth. The variables identified as relevant were: bank obligations, assets at the central bank and commercial banks, and private sector loans. Also, for these authors, financial, legal, and accounting reforms that are favorable to the rights of creditors are the most beneficial to financial development and growth. In Nazmi (2005) the suggested mechanism is that the development of commercial banks ensures greater capital deepening in business. King and Levine (1993) also confirm this finding through variables such as the ratio of liquid liabilities to GDP, the link between bank deposits and credit supply, the share of credit granted by non-financial firms in the global credit, and the ratio of credit granted by non-financial firms as a proportion of GDP.

The proposal that financial expansion is facilitated by economic growth and the development of domestic markets for goods (through the demand for credit, deposits and payments system) is known as demand-following. This approach highlights the contributions from Demetriades and Hussein (1996), Arestis and Demetriades (1997), Calderón and Liu (2003), Ang and McKibbin (2007), and Bittencourt (2012). In particular, Arestis and Demetriades (1997) include variables such as the stock market capitalization ratio, the stock market volatility, the ratio of $M 2$ to GDP, and the ratio of domestic bank credit to nominal GDP. They find different features for Germany and the United States. While in Germany financial development affects the GDP, in the United States there is not enough evidence to support this relationship, but it does appear that the GDP contributes to the expansion of the financial sector.

Calderón and Liu (2003) test the bidirectional premise in 109 developing industrial countries. They find that this occurs mostly in developing countries, and they also show the greatest influence of financial development on GDP. Bittencourt (2012) analyzes a number of Latin American countries (Argentina, Bolivia, Brazil and Peru), between 1980 and 2007, obtaining that macroeconomic stability (low inflation), institutional development (seen as fiscal responsibility and independence of the central bank), and structural reforms are necessary conditions for economic growth. Finally, Huang (2010), provides a comprehensive analysis to explain the determi- 
nants of financial development, he finds that these determinants are the aggregate private investment, macroeconomic policies, financial reforms, and institutional improvement.

Among the most important studies that support the bidirectional causality between financial development and economic growth are those from Greenwood and Smith (1997), Al-Yousif (2002), and Rajan and Zingales (2003). In particular, Al-Yousif (2002), based on evidence from 30 developing countries (mainly Asian and African countries) during the period between 1970 and 1999, finds evidence of the bidirectional hypothesis, but argues that it cannot be generalized because it depends on the efficiency of institutions. Interestingly, he uses two proxies to measure financial development: the ratio of currency / narrow money stock $(M 1)$, and the ratio of broad money stock M2 to nominal GDP. Finally, Rajan and Zingales (2003) highlight the importance of openness in terms of international trade and free capital flows on financial development and growth.

It is also worth emphasizing that there is another relevant area to the empirical discussion, though less studied, concerning to the effects of financial inclusion on economic growth. In this regard, it is important to point out that microfinance studies are mainly interested in questions such as: whether financial services are accessible to all people regardless of their purchasing power, and whether access to these services creates new opportunities and benefits for the population.

On the other hand, Demirguc-Kunt and Klapper (2012) analyze some indicators of the Global Findex developed by the World Bank. They find significant differences between developing and developed economies. For example, they noted that the number of financial accounts maintained by adults is more than twice in advanced economies over developing countries. Furthermore, in developing countries the population differences are deepened. In these countries there is a gender gap of 69 points across income groups, and there is also a gender difference in access to financial services; while 46 percent of men have a formal account, this figure is only 37 percent for women. Other related works are: Hannig and Jansen (2010) who state that the potential costs of financial inclusion are compensated by improvements in financial stability; Thorsten et al. (2006) observe that institutional development is a relevant factor in explaining access to funding sources, as expected. They emphasize that the larger the companies, the highest lifetime or age in the market, and firms with foreign ownership of capital are those with greater access to financing; and, finally, Sengupta and Aubuchon (2008) who find that the model of Grameen Bank of Bangladesh through its microfinance services (in various regions of the world) contributes to improving the quality of life of the poor population. 


\section{Macroeconomic and financial indicators}

This section briefly presents some economic and financial indicators that will be useful to examine the relationship between financial development and economic growth in Latin American countries.

\subsection{Macroeconomic conditions}

As noted above, several studies agree on the relationship between macroeconomic stability and financial and economic performance. In the countries examined in the present research (Argentina, Brazil, Chile, Colombia, Mexico, Uruguay and Venezuela) there are several macroeconomic coincidences in recent years. Most of them show favorable growth rates of GDP, gross savings and gross fixed capital formation, with the exception of Venezuela and Argentina. In addition, most of these countries have stable inflation and constant levels of foreign direct investment, except Venezuela.

\subsection{Financial sector}

The main features observed for the commercial banking sector are: 1) for most of the countries in the studied region there is an increasing concentration of banking services, 2) only in Colombia and Chile is the lending rate higher than the rate of deposits received, 3) Mexico and Uruguay are the countries in which the share of foreign bank assets to total assets is highest (75\% and 48\%, respectively), 4) bank credit in the private sector is highest in Brazil and Chile $(68.9 \%$ and $46.9 \%$, respectively), and, finally, 5) bank credit to the government is at its highest in Brazil $(37.9 \%)$ and at its lowest in Chile (1.73\%).

The dynamics of the capital markets show the course of investor confidence in listed companies and the institutional conditions of the sector, as well as the willingness of firms to capitalize and have presence in the market. In cases such as Brazil, Chile, Colombia, and Mexico, firms increased their capitalization in the stock market between 2000 and 2010; in contrast, the capitalization was reduced substantially in Uruguay and Venezuela. In some of the countries studied there was a reduction in the number of domestic companies listed on stock exchanges, and this is a sign that the economies are susceptible to international crisis. The reduction in the volatility of the stock index in Chile is also noticeable, which contrasts with the observed increases in other countries. Moreover, the average rates of Return on Assets $(R O A)$ have increased in Argentina, Brazil, and Colombia, and have decreased in other cases, including Mexico. The Return on Equity $(R O E)$ reveals the degree of financial leverage between companies, which is observed on a larger scale 
in Argentina and Colombia. Figure 1 shows the weak evidence of association between the GDP growth of selected countries and the representative variables of financial development.

\section{Figure 1. OLS regression lines for Argentina, Brazil, Chile, Colombia, Mexico,} Uruguay and Venezuela, 1990-2011
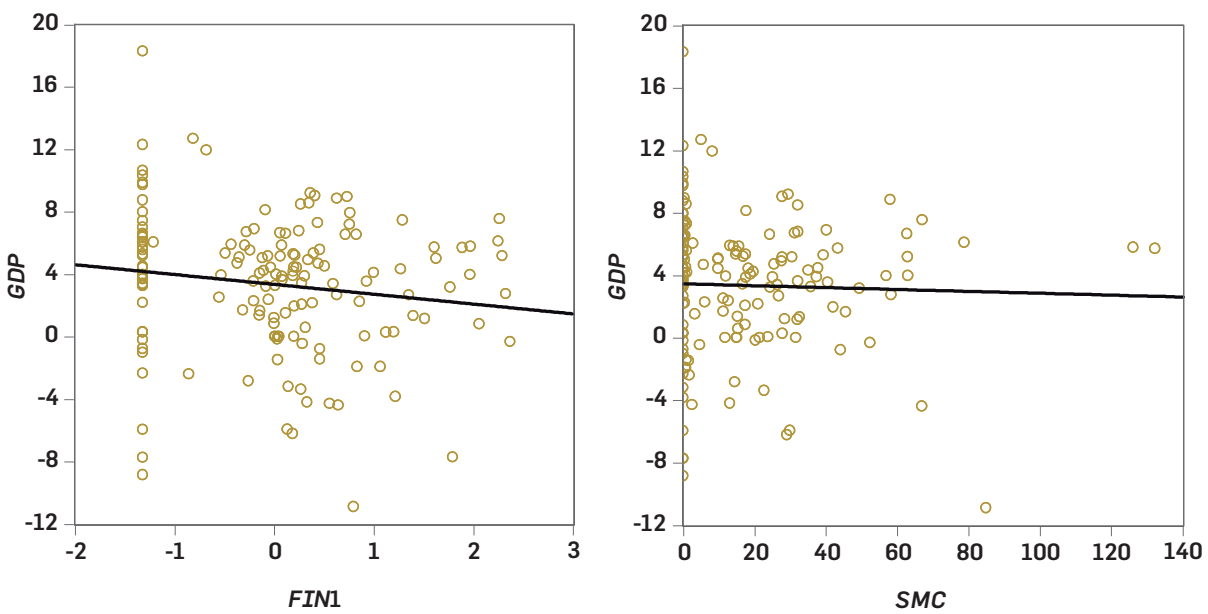

(FIN1 for financial development and SMC for stock market capitalization)

SOURCE: AUTHOR'S OWN ELABORATION.

\subsection{Financial inclusion}

As has been noted above, the World Bank has recently developed a set of indicators of financial inclusion (Global Findex), some of these indicators are presented in Table 1. In several countries - Chile, Colombia, Mexico, and Uruguay for instance, financial inclusion measures are aimed at expanding the supply of credit to both the higher income and lower income population. In a further group of countries, including Brazil and Venezuela, the inclusion aims to promote the use of financial services, especially of accounts for salary payments and transactions. Interestingly, other measures relating to the economic condition of people in the countries studied, such as the poverty gap between 2000 and 2010 were constricted, but uncertainty exists regarding changes in the purchasing power of the population.

In fact, in almost all the studied economies, consumer spending decreased; this situation could be due to an increase in savings. Gender differences in access to financial services are evident in all of the countries of the region - women have less access to bank savings, loans, and a lower proportion of them maintain bank accounts to receive their salaries. 
Table 1. Some financial inclusion indicators (data for 2011)

\begin{tabular}{cccccccc}
\hline Indicator & Argentina & Brazil & Chile & Colombia & Mexico & Uruguay & Venezuela \\
\hline A & 4 & 3 & 6 & 5 & 6 & 4 & 1 \\
\hline B & 1.42 & 5.76 & 4.84 & 3.82 & 2.67 & 2.13 & 4.29 \\
\hline C & 5.63 & 13.30 & 17.72 & 14.26 & 9.44 & 8.07 & 19.79 \\
\hline D & 0.20 & 0.80 & 1.04 & 0.91 & 1.95 & 0.15 & 0.32 \\
\hline E & 0.55 & 1.70 & $\mathbf{5 . 2 8}$ & $\mathbf{4 . 1 9}$ & 3.23 & 3.03 & 0.55 \\
\hline F & 13.71 & 19.67 & 11.03 & $\mathbf{2 6 . 3 4}$ & $\mathbf{2 3 . 9 7}$ & $\mathbf{2 1 . 7 0}$ & 9.54 \\
\hline G & 16.97 & 26.58 & $\mathbf{2 9 . 1 7}$ & $\mathbf{4 1 . 0 0}$ & $\mathbf{3 3 . 4 3}$ & $\mathbf{2 6 . 0 2}$ & 15.98 \\
\hline H & 5.83 & $\mathbf{1 4 . 8 7}$ & 7.12 & 7.50 & 4.60 & 2.90 & 18.17 \\
\hline I & 23.54 & $\mathbf{3 8 . 2 0}$ & 29.38 & 29.48 & 20.42 & 18.89 & 35.77 \\
\hline J & 22.83 & $\mathbf{4 1 . 2 4}$ & 25.80 & 15.47 & 12.08 & 10.52 & 31.27 \\
\hline K & 41.05 & $\mathbf{6 5 . 6 1}$ & $\mathbf{5 3 . 6 5}$ & $\mathbf{4 4 . 4 8}$ & 37.68 & 32.23 & 52.73 \\
\hline
\end{tabular}

Notes:A. Strength of legal rights index $(0=$ weak to $10=$ strong), B. Saved at a financial institution in the past year, income, bottom $40 \%$, C. Saved at a financial institution in the past year, income, top $60 \%$, D. Outstanding loan to purchase a home, income, bottom $40 \%$, E. Outstanding loan to purchase a home, income, top $60 \%$, F. Loan in the past year, income, bottom $40 \%$, G. Loan in the past year, income, top $60 \%$, H. Account used to receive wages, income, bottom $40 \%$, I. Account used to receive wages, income, top $60 \%$, J.Account at a formal financial institution, income, bottom $40 \%$, K. Account at a formal financial institution, income, top $60 \%$.

SOURCE:WORLD BANK.

\section{Econometric analysis}

In order to analyze the relationship between financial development and financial inclusion with economic growth, a panel data analysis for the period 1990-2011 is performed for Argentina, Brazil, Chile, Colombia, Mexico, Uruguay, and Venezuela ( $T=22$ y $N=7$ ); the analysis follows the work from Huang (2010) and Bittencourt (2012).

These countries were chosen because they have the regions higher per capita GDP in the period considered according to World Bank statistics. Using data from this international organization the estimated model considers the growth rate of per capita $G D P(G D P)$ as a function of the following variables: gross fixed capital formation $(G F C F)$, exports of goods and services $(E X)$, imports of goods and services (IM), general government financial consumption expenditure $(G O B)$, and gross savings $(G S)$, all of them as a percentage of GDP.

From financial development variables such as: bank deposits $(B D)$, liquid liabilities $(L L)$, stock market capitalization $(S M C)$, central bank assets $(C B A)$, and financial system deposits (FSD), a variable, FIN1, was constructed by using a principal component analysis to extract the unobserved values of the preceding series. According to the eigenvalues obtained, the first principal component explains $74.51 \%$ of the total variance of financial development, and the second principal component explains $18.92 \%$ of the total variance. Thus, the basic equation is given by: 


$$
G D P_{i t}=\alpha_{i}+\beta G F C G_{i t}+\gamma E X_{i t}+\delta I M_{i t}+\varepsilon G O B_{i t}+\in G S_{i t}+\zeta F I N 1_{i t}+e_{i t}
$$

The null hypothesis of unit root or non-stationarity was examined with the Im, Pesaran and Shin (IPS) test. In Table 2 it is shown, in all cases, that the null hypothesis is rejected in favor of the alternative that at least one variable in each country is stationary. Table 3 shows the results of the proposed models: Pooled Ordinary Least Squares (POLS), Fixed Effect in static and dynamic cases (FE1 and FE2), Random Coefficients $(R C)$ and Fixed $\zeta$ Effects with Instrumental Variables (FE-IV).

Table 2. Panel unit-root test

\begin{tabular}{ll}
\hline Variable & IPS statistics \\
\hline GDP & -3.66243 \\
\hline GFCF & -1.78380 \\
\hline$E X$ & -1.36705 \\
\hline$I M$ & -1.61400 \\
\hline$G O B$ & -2.97160 \\
\hline$G S$ & -0.57055 \\
\hline FIN1 & -0.09643 \\
\hline
\end{tabular}

SOURCE: AUTHOR'S OWN CALCULATIONS.

Table 3. POLS, FE, $R C$, and $F E$-IV estimations on GDP

\begin{tabular}{lcccccc}
\hline GDP & POLS & FE1 & FE2 & RC & FE-IV1 & FE-IV2 \\
\hline GFCF & $0.045(0.25)$ & $-0.433(-2.70)$ & $-0.399(-2.47)$ & $0.045(0.30)$ & $-0.433(-1.58)$ & $-0.399(-1.45)$ \\
\hline EX & $-0.120(-0.90)$ & $-0.490(-3.01)$ & $-0.416(-2.17)$ & $-0.120(-0.89)$ & $-0-490(-2.47)$ & $-0.416(-2.02)$ \\
\hline IM & $0.092(0.65)$ & $0.553(2.67)$ & $0.438(1.89)$ & $0.092(0.64)$ & $0.553(2.22)$ & $0.438(1.71)$ \\
\hline GOB & $-0.235(-1.84)$ & $-0.573(-2.91)$ & $-0.631(-4.00)$ & $-0.235(0.13)$ & $-0.573(-3.42)$ & $-0.631(-3.586)$ \\
\hline GS & $0.107(0.77)$ & $0.551(5.22)$ & $0.523(4.50)$ & $0.107(1.05)$ & $0.551(2.85)$ & $0.523(2.692)$ \\
\hline FIN1 & $-0.009(-0.01)$ & $-0.202(-0.41)$ & $-0.168(-0.30)$ & $-0.009(-0.02)$ & $-0.202(-0.30)$ & $-0.168(-0.260)$ \\
\hline GDPt-1 & & & $0.189(1.97)$ & & & $0.189(2.28)$ \\
\hline$F$ test & 1.473 & 2.423 & 3.109 & & & \\
\hline$F^{\star}$ test & & & & & & \\
\hline Hausman & & & & & 3.23 & 3.28 \\
\hline LR test & 0.171 & 0.233 & 0.097 & 0.171 & 0.233 \\
\hline$R^{2}$
\end{tabular}

t-ratios in parentheses.

SOURCE:AUTHOR'S OWN CALCULATIONS.

While the pooled regression model assumes homogeneity for the intercepts, the fixed effects estimator considers the heterogeneity of them, and the random effects model 
assumes heterogeneity of slops and intercepts. To determine the model that best fits, we use the Breusch-Pagan test known as the Lagrange Multiplier for random effects in order to identify whether there is a difference between the pooled regression and the random effects regression. The null hypothesis for this test states that the error variance associated with the individual part $u_{i t}$ is zero, then if in (1) $\alpha_{i}=\alpha+u_{i}$ is used, the random effects model turns out to be:

$$
G D P_{i t}=\alpha+\beta G F C F_{i t}+\gamma E X_{i t}+\delta I M_{i t}+\varepsilon G O B_{i t}+\in G S_{i t}+\zeta F I N 1_{i t}+u_{i}+e_{i t}
$$

Thus, it will be tested that $H_{0}: \sigma_{u}^{2}$ against the alternative hypothesis $H_{1}: \sigma_{u}^{2}>0$. The results shows that $P\left(C V \geq \chi^{2}\right)=0.005$, so $H_{0}$ can be rejected, and it is determined that it is preferable to use the random effects model instead of pooled data. Also, the $F$ test will be performed to establish whether the pooled regression or fixed effects regression is preferable. In this case, the hypothesis to test is $H_{0}: v_{1}=v_{2}=\cdots=v_{i}$, that is, all dichotomous variables are equal, against $H_{1}: v_{1} \neq v_{2} \neq \cdots \neq v_{i}$. Given the estimated $F$ values, the null hypothesis that the individual effects are equal is rejected and it is preferable to use the fixed effect model as opposed to the pooled regression model.

The Hausman test considers the null hypothesis that the individual error component and the explanatory variables are not related, $H_{0}: \operatorname{Corr}\left(u_{i}, X\right)=0$. The test results reject the null hypothesis, so it is preferable to use the fixed effect model. To avoid the problem of exogeneity and considering the assumption that there is reverse causality, in the sense that economic growth contributes to financial development, then a model with instrumental variables, in the static and dynamic, will be used; inflation being the main variable.

The results of the regressions are shown in Table 3, it should be emphasized that even in the models that best fit, there is not enough evidence that financial development leads to economic growth. The other variables, mainly associated with macroeconomic conditions, are significant in explaining growth; especially contributing to growth in the increase in both imports $(I M)$ and gross savings $(G S)$. When the Granger causality test to panel data is performed, it is found that there is a relationship between some variables of financial development and GDP growth. In particular, it can be argued that stock market capitalization (SMC) does cause GDP growth, and that this, in turn, leads to growth of central bank assets $(C B A)$.

\section{Conclusions}

This research has examined the relationship between financial development and financial inclusion with economic growth in countries with higher per capita GDP in 
Latin America. The main finding is that there is no clear evidence of a relationship between financial sector development and economic growth. Specifically, there is no evidence that the characteristics of the financial sector, by themselves, have a determining influence on growth. Needless to say, the additional or complementary factors or financial variables that could have effects on the real sector remain to be specified. Some of these explanatory variables may be associated with the macroeconomic conditions of the region, such as price stability and interest rates, as well as policies aimed at promoting savings and gross capital formation and/or the strength of institutions.

Although the proposed econometric model has joint significance, the financial explanatory variables showed limited individual significance. The most significant variables in explaining economic growth were central bank assets, stock market capitalization, and some macroeconomic variables such as imports and gross savings. From these obtained results there are two lines of future research: 1) to determine which variables associated with the financial sector (or which combination of them) have a greater impact on economic growth, and 2) to determine whether some differences could be established by comparing the impacts of these variables with the degree of economic development between countries with higher and lower GDP growth.

\section{Acknowledgments}

The authors gratefully acknowledge the comments and suggestions of the peer reviewers for their very professional job improving substantially the work.

\section{References}

Acaravci, S. K., Ozturk, I. and Acaravci, A. (2009). Financial Development and Economic Growth: Literature Survey and Empirical Evidence from Sub-Saharan African Countries, South African Journal of Economic \& Management Sciences, 16(2), pp. 11-27.

Aghion, P., Bacchetta, P. and Banerjee, A. (2004). Financial Development and the Instability of Open Economies, Journal of Monetary Economics, 51(6), pp. 1077-1106.

Al-Yousif, Y.K. (2002). Financial Development and Economic Growth: Another Look at the Evidence from Developing Countries, Review of Financial Economics, 11(2), pp. 131-150.

Ang, J.B. and McKibbin, W.J. (2007). Financial Liberalization, Financial Sector Development and Growth: Evidence from Malasya, Journal of Development Economics, 84(1), pp. 215-233. 
Arestis, P. and Demetriades, P. (1997). Financial Development and Economic Growth: Assessing the Evidence, The Economic Journal, 107(442), pp. 783-799.

Bencivenga, V.R. and Smith, B.D. (1991). Financial Intermediation and Endogenous Growth, Review of Economic Studies, 58(2), pp. 195-209.

Bittencourt, M. (2012). Financial Development and Economic Growth in Latin America: Is Schumpeter Right? Journal of Policy Modeling, 34(3), pp. 341-355.

Calderón, C. and Liu, L. (2003). The Direction of Causality between Financial Development and Economic Growth, Journal of Development Economics, 72(1), pp. 321-334.

De Gregorio, J. and Guidotti, P. E. (1995). Financial Development and Economic Growth, World Development, 23(3), pp. 443-448.

Demetriades, P. and Hussein, K. (1996). Financial Development and Economic Growth: Cointegration and Causality Tests for 16 Countries, Journal of Development Economics, 51(2), pp. 387-411.

Demirguc-Kunt, A. and Klapper, L. (2012). Measuring Financial Inclusion, The Global Findex Database, Policy Research Working Paper No. 6025, The World Bank.

Federici, D. and Caprioli, F. (2009). Financial Development and Growth: An Empirical Analysis, Economic Modelling, 26(2), pp. 285-294.

Greenwood, J. and Jovanovic, B. (1990). Financial Development, Growth, and the Distribution of Income, Journal of Political Economy, 98(5), pp. 1076-1107.

Greenwood, J. and Smith, B.D. (1997). Financial Markets in Development and the Development of Financial Markets, Journal of Economic Dynamic and Control, 21(1), pp. 145-181.

Gupta, K. L. (1984). Finance and Economic Growth in Developing Countries, Croom Helm Ltd., London.

Hannig, A. and Jansen, S. (2010). Financial Inclusion and Financial Stability: Current Policy Issues, ADBI Working Paper No. 259, Asian Development Bank Institute.

Huang, Y. (2010). Determinants of Financial Development, Palgrave Macmillan, Great Britain.

King, R.G. and Levine, R. (1993). Finance and Growth: Schumpeter Might Be Right, Quarterly Journal of Economics, 108(3), pp. 717-738.

Kose, M. A., Prasas, E.S. and Terrones, M.E. (2003). Financial Integration and Macroeconomic Volatility, IMF Staff Papers, 50, pp. 119-142.

Levine, R., Loayza, N. and Beck, T. (2000). Financial Intermediation and Growth: Causality and Causes, Journal of Monetary Economics, 46(1), pp. 31-77.

Mckinnon, R. (1973). Money and Capital in Economic Development, Brookings Institution, Washington.

Nazmi, N. (2005). Deregulation, Financial Deepening and Economic Growth: The Case of Latin America, The Quarterly Review of Economics and Finance, 45(2-3), pp. 447-459.

Prasad, E.S., Rajan, R.G. and Subramanian, A. (2007). Foreign Capital and Economic Growth, NBER Working Paper No. 13619.

Rajan, R.G. and Zingales, L. (2003). The Great Reversals: The Politics of Financial Development in the Twentieth Century, Journal of Financial Economics, 69(1), pp. 5-50. 
Sengupta, R. and Aubuchon, C.P. (2008). The Microfinance Revolution: An Overview, Federal Reserve Bank of St. Louis Review, 90(1), pp. 9-30.

Shaw, E. S. (1973). Financial Deepening in Economic Development, Oxford University Press, USA.

Thorsten, B., Demirguc-Kant, A., Laeven, L. and Maksimovic, V. (2006). The Determinants of Financing Obstacles, Journal of International Money and Finance, 25(6), pp. 932-952. 